\title{
Purification and characterization of native human insulin-like growth factor binding protein-6
}

\author{
Andrea Taferner $\cdot$ Lucia Micutkova . \\ Martin Hermann • Pidder Jansen-Dürr • \\ Haymo Pircher
}

Received: 3 February 2011 / Accepted: 28 February 2011 / Published online: 23 March 2011

(C) The Author(s) 2011. This article is published with open access at Springerlink.com

\begin{abstract}
Insulin-like growth factor binding proteins (IGFBPs) are key regulators of insulin-like growth factor (IGF) mediated signal transduction and thereby can profoundly influence cellular phenotypes and cell fate. Whereas IGFBPs are extracellular proteins, intracellular activities were described for several IGFBP family members, such as IGFBP-3, which can be reinternalized by endocytosis and reaches the nucleus through routes that remain to be fully established. Within the family of IGFBPs, IGFBP-6 is unique for its specific binding to IGF-II. IGFBP-6 was described to possess additional IGFindependent activities, which have in part been attributed to its translocation to the nucleus; however, cellular uptake of IGFBP-6 was not described. To further explore IGFBP-6 functions, we developed a new method for the purification of native human IGFBP-6 from cell culture supernatants, involving a four-step affinity purification procedure, which yields highly enriched IGFBP-6. Whereas protein purified in this way retained the capacity to interact with IGF-II and modulate IGF-dependent signal transduction, our data suggest that, unlike IGFBP-3, human IGFBP-6 is not readily internalized by human tumor cells. To summarize,
\end{abstract}

Electronic supplementary material The online version of this article (doi:10.1007/s12079-011-0126-2) contains supplementary material, which is available to authorized users.

A. Taferner $\cdot$ L. Micutkova $\cdot$ P. Jansen-Dürr $\cdot H$. Pircher $(\triangle)$ Institute for Biomedical Aging Research, Austrian Academy of Sciences, Rennweg 10,

6020 Innsbruck, Austria

e-mail: haymo.pircher@oeaw.ac.at

\section{Hermann}

KMT Laboratory, Department of Visceral, Transplant and Thoracic Surgery, Center of Operative Medicine, Innsbruck Medical University, Innrain 66,

6020 Innsbruck, Austria this work describes a novel and efficient method for the purification of native human insulin-like growth factor binding protein 6 (IGFBP-6) from human cell culture supernatants, applying a four-step chromatography procedure. Intactness of purified IGFBP-6 was confirmed by IGF ligand Western blot and ability to modulate IGFdependent signal transduction. Cellular uptake studies were performed to further characterize the purified protein, showing no short-term uptake of IGFBP-6, in contrast to IGFBP-3.

Keywords IGF-binding protein · Purification · Chromatography $\cdot$ Cellular uptake

$\begin{array}{ll}\text { Abbreviations } \\ \text { HDF } & \text { Human diploid fibroblast } \\ \text { HIC } & \text { Hydrophobic interaction chromatography } \\ \text { IGF } & \text { Insulin-like growth factor } \\ \text { IGFBP } & \text { Insulin-like growth factor binding protein } \\ \text { MW } & \text { Molecular weight }\end{array}$

\section{Introduction}

Insulin-like growth factor binding proteins (IGFBPs) and the CCN (Cyr61, CTGF and Nov) proteins form two related extracellular protein families that share a similar amino terminal domain (Kim et al. 1997). While the main function of IGFBPs is to modulate the action and biological availability of IGFs (Firth and Baxter 2002), CCNs show a weaker affinity to IGFs and are mostly known for their IGFindependent functions (Holbourn et al. 2008). Both protein families were linked to processes like cell growth, apoptosis, cell migration, carcinogenesis, and aging (Baxter 2000; 
Perbal 2004). The expression of the various IGFBPs is differentially regulated in a tissue-dependent fashion (Cerro et al. 1993), suggesting that each IGFBP exerts a specific role. IGFBP-6 stands out due to its preferential binding to IGF-II (Martin et al. 1990), and was shown to inhibit the growth of tumors that are dependent on IGF-II signalling (Gallicchio et al. 2001; Grellier et al. 1998; Kim et al. 2002; Kuo et al. 2010; Sueoka et al. 2000). Several transcription factors such as Gli1 (Xu et al. 2009) were shown to regulate IGFBP-6 expression (Dailly et al. 2001).

For some of the best studied IGF binding proteins, in particular IGFBP-3 and IGFBP-5, additional functions have been described which are not mediated by their ability to sequester IGFs, as best demonstrated by the use of IGF non-binding mutants (Hong et al. 2002). In the case of IGFBP-3, IGF-independent actions seem to require intracellular IGFBP-3, which can be re-internalized by endocytosis. In addition, both IGFBP-3 and -5 contain functional nuclear localization sites and both proteins can be imported to the nucleus by an importin-dependent pathway (Schedlich et al. 2000). While IGFBP-6 has been mainly noted for its inhibition of IGF-II signalling, there is growing evidence for IGF-independent actions also in the case of IGFBP-6. One example for such actions is the induction of cancer cell migration by IGFBP-6 (Fu et al. 2007, 2010). Recently, a functional nuclear localization signal (NLS) was reported for IGFBP-6, mediating its nuclear import by importin- $\alpha$ (Iosef et al. 2008) in permeabilized cells, and IGFBP-6 was identified as new interaction partner for the nuclear protein Ku80 (Iosef et al. 2010). However, it is unclear how IGFBP6 can enter intact cells and, unlike in the case of the related proteins IGFBP-3 and -5 , endocytic uptake of extracellular IGFBP-6 was not described.

Since IGFBP-6 was identified as a strong oncosuppressor (see above), it may be possible to use it as a therapeutical agent against certain tumors, as has been demonstrated for the related protein IGFBP-3 before (Liu et al. 2005). Since its first description, several procedures to purify IGFBP-6 from various sources have been described. Small amounts of hIGFBP-6 have been purified from conditioned medium of transformed human fibroblasts by hydrophobic interaction chromatography (HIC) and reverse-phase HPLC (Martin et al. 1990). Alternatively, IGF-II affinity purification followed by reverse-phase HPLC has been utilized to purify hIGFBP6 produced by PC-3 cells (Srinivasan et al. 1996). On a larger scale, purification has been done from supernatants of recombinant Pichia pastoris strains expressing and secreting hIGFBP-6, using ion exchange chromatography and HIC (Chen et al. 2007). To provide a gentle and efficient procedure to obtain $\mathrm{mg}$ quantities of recombinant hIGFBP-6 secreted from human cells, we have explored the biosynthetic capacities of human osteosarcoma cells
(U-2OS) which were successfully used for highly efficient ectopic production of other human proteins, including IGFBP-3 (Pircher et al. 2010). In this communication, we used an efficient purification procedure independent of the IGF-II binding capacity of hIGFBP-6 to produce highly pure IGFBP-6 protein.

\section{Materials and methods}

\section{Cell culture}

U-2OS human osteosarcoma cells were obtained from ATCC (American Type Culture Collection, Wesel, Germany). Human diploid fibroblasts (HDF) were isolated from human foreskin of newborns (Wagner et al. 2001). U-2OS overexpressing IGFBP-6 were maintained in Dulbecco's modified Eagle's medium (DMEM) containing Glutamax (Gibco Invitrogen, Lofer, Austria), which was supplemented with $10 \%$ heat-inactivated fetal bovine serum (FBS; Biochrom, Berlin, Germany), $100 \mathrm{U} / \mathrm{ml}$ penicillin with $0.1 \mathrm{mg} / \mathrm{ml}$ streptomycin (Gibco Invitrogen, Lofer, Austria) and $200 \mu \mathrm{g} / \mathrm{ml}$ hygromycin B (BD Biosciences Clontech, Palo Alto, CA, USA). All other cell types were maintained in DMEM (Sigma, Vienna, Austria), supplemented with $10 \%$ heat-inactivated FBS, $4 \mathrm{mM}$ L-glutamine (Gibco Invitrogen, Lofer, Austria) and $100 \mathrm{U} / \mathrm{ml}$ penicillin with $0.1 \mathrm{mg} / \mathrm{ml}$ streptomycin. The cells were grown in an atmosphere of $5 \% \mathrm{CO}_{2}$ at $37^{\circ} \mathrm{C}$ and were subcultured by trypsinization with $0.05 \%$ trypsin-EDTA (Gibco Invitrogen, Lofer, Austria) every 3-4 days.

\section{Generation of stable IGFBP-6 overexpressing U-2OS} clones

$2 \mu \mathrm{g}$ of pcDNA3.1/Hygro(-) plasmid containing IGFBP-6 cDNA (GenBank: NM_002178, introduced via XhoI and HindIII restriction sites) along with $6 \mu$ l of Lipofectamine 2000 (Invitrogen, Lofer, Austria) were used for transfection of $80 \%$ confluent U-2OS in a $35 \mathrm{~mm}$ dish. $4 \mathrm{~h}$ after transfection, cells were washed with medium and cultivated for additional $48 \mathrm{~h}$ in DMEM. Subsequently, cells were put under selection by addition of $200 \mu \mathrm{g} / \mathrm{ml}$ hygromycin B (BD Biosciences Clontech, Palo Alto, CA, USA). The medium containing hygromycin B was replaced every 2 days until the cells reached confluency. Cells were then re-seeded on $145 \mathrm{~mm}$ dishes, and 24 single, isolated cells were picked from the dish with a sterile pipet tip and expanded in individual wells. Cell supernatants of all individual stable clones were tested for IGFBP-6 levels by ELISA, and the clone showing the highest level of IGFBP6 expression was selected for the harvesting of conditioned media. 
Harvesting of U-2OS cell supernatants containing IGFBP-6

$3 \times 10^{6}$ U-2OS cells, stably overexpressing IGFBP-6, were seeded on 25 large $(145 \mathrm{~mm})$ dishes each. Two days later the cells were washed twice with PBS, and $12.5 \mathrm{ml}$ of fresh serum-free DMEM was added to the cells. 3 days later the medium was harvested and substituted with $12.5 \mathrm{ml}$ of fresh serum-free medium. The harvested medium was centrifuged at $300 \mathrm{~g}$, and the supernatant was frozen at $-20^{\circ} \mathrm{C}$. Harvesting was repeated up to 8 times every 3 days.

\section{Cation exchange chromatography of IGFBP-6}

$230 \mathrm{ml}$ of harvested cell culture supernatant were supplemented with four protease inhibitor tablets (Complete, Roche, Vienna, Austria) and $25 \mathrm{ml}$ of $500 \mathrm{mM}$ sodium acetate, $\mathrm{pH}$ 4.5. After filtration through a $0.45 \mu \mathrm{m}$ bottletop filter (Steritop, Millipore, Schwalbach, Germany) the cleared supernatant was applied to a $8 \mathrm{ml}$ cation exchange column (Mono S, GE Healthcare, Vienna, Austria) attached to an ÄKTA purifier system (GE Healthcare, Vienna, Austria) and previously equilibrated with buffer B (50 $\mathrm{mM}$ sodicum acetate, $1 \mathrm{M} \mathrm{NaCl}, \mathrm{pH} 4.5$ ) followed by buffer A ( $50 \mathrm{mM}$ sodium acetate, $100 \mathrm{mM} \mathrm{NaCl}, \mathrm{pH}$ 4.5). After washing with buffer $\mathrm{A}$, protein bound to the column was eluted by applying a linear $85 \mathrm{ml}$ salt gradient ranging from buffer $\mathrm{A}$ to buffer $\mathrm{B}$ and collected in $2 \mathrm{ml}$ fractions. The main peak fractions $(20 \mathrm{ml})$ were pooled and concentrated to a volume of $1-2 \mathrm{ml}$ using a centrifugal filter device (Amicon Ultra, Millipore, Schwalbach, Germany).

\section{Hydrophobic interaction chromatography of IGFBP-6}

The pool of the ion exchange purification was mixed with 10 volumes of buffer A (30\% saturated ammonium sulfate in $50 \mathrm{mM}$ sodium phosphate, $100 \mathrm{mM} \mathrm{NaCl}, \mathrm{pH} \mathrm{7.0)}$ ), cleared by centrifugation, and applied to a $5 \mathrm{ml}$ HIC column (HiTrap Phenyl HP, GE Healthcare, Vienna, Austria) attached to an ÄKTA purifier system (GE Healthcare, Vienna, Austria) and previously equilibrated with buffer A. Protein bound to the column was eluted by applying a linearly decreasing $80 \mathrm{ml}$ salt gradient ranging from buffer A to buffer B $(50 \mathrm{mM}$ sodium phosphate, $100 \mathrm{mM} \mathrm{NaCl}, \mathrm{pH} \mathrm{7.0)}$ and collected in $2 \mathrm{ml}$ fractions. The main peak fractions $(18 \mathrm{ml})$ were pooled and concentrated to a volume of 1-2 $\mathrm{ml}$ using a centrifugal filter device.

Heparin affinity chromatography of IGFBP-6

The pool of the HIC purification was mixed with 10 volumes of buffer A (30 mM sodium phosphate, $50 \mathrm{mM}$ $\mathrm{NaCl}, \mathrm{pH} 7.0$ ), concentrated to $1-2 \mathrm{ml}$, and applied to a
$1 \mathrm{ml}$ Heparin column (HiTrap Heparin HP, GE Healthcare, Vienna, Austria) attached to an ÄKTA purifier system (GE Healthcare, Vienna, Austria) and previously equilibrated with buffer A. Protein bound to the column was eluted by applying a linear $30 \mathrm{ml}$ salt gradient ranging from buffer A to buffer $\mathrm{B}(30 \mathrm{mM}$ sodium phosphate, $1 \mathrm{M} \mathrm{NaCl}, \mathrm{pH} 7.0)$ and collected in $2 \mathrm{ml}$ fractions. The main peak fractions containing IGFBP-6 $(8 \mathrm{ml})$ were pooled and concentrated to a volume of 1-2 $\mathrm{ml}$ using a centrifugal filter device.

\section{Size exclusion chromatography of IGFBP-6}

The pool of the heparin purification was applied to a $120 \mathrm{ml}$ gel filtration column (HiLoad Superdex G75 16/60, GE Healthcare, Vienna, Austria) attached to an ÄKTA purifier system (GE Healthcare, Vienna, Austria) and previously equilibrated with gel filtration buffer $(50 \mathrm{mM}$ sodium phosphate, $100 \mathrm{mM} \mathrm{NaCl}, \mathrm{pH}$ 7.0). Samples were collected in $2 \mathrm{ml}$ fractions. The main peak fractions containing IGFBP-6 $(8 \mathrm{ml})$ were pooled and concentrated to a volume of 1-2 $\mathrm{ml}$ using a centrifugal filter device. Aliquots were shock-frozen in liquid nitrogen and stored at $-80^{\circ} \mathrm{C}$.

Qualitative and quantitative evaluation of purified IGFBP-6

Standard silver staining and Western blot protocols were used to monitor the progress of the purification and perform qualitative evaluation of the samples. For Western blot, a mouse monoclonal antibody raised against recombinant human IGFBP-6 (MAB8761, R\&D Systems Europe, Abingdon, UK) was used as primary antibody at a dilution of 1:2,000 (for analysis of crude cell supernatants) to 1:40,000 (for analysis of purification steps), HRP-linked polyclonal goat anti-mouse antibody (P0447, Dako, Glostrup, Denmark) was used as secondary antibody. Quantitative analysis was performed by ELISA (DuoSet human IGFBP-6, R\&D Systems Europe, Abingdon, UK) according to the manufacturer's protocol.

\section{IGF ligand Western blot}

$450 \mathrm{ng}$ of purified IGFBP- 6 and $20 \mathrm{ng}$ of purified IGFBP-3 (Pircher et al. 2010) were separated by SDS-PAGE, transferred to a PVDF membrane, and probed with biotinylated human IGF-II using an IGFBP Westernligand blotting kit (IBT Systems, Reutlingen, Germany) according to the manufacturer's protocol.

IGF-II-dependent Akt phosphorylation

HDF at passage 8 were plated at a density of 150,000 cells per 6-well in DMEM supplemented with 10\% FCS, $4 \mathrm{mM}$ 
L-glutamine, $100 \mathrm{U} / \mathrm{ml}$ penicillin and $0.1 \mathrm{mg} / \mathrm{ml}$ streptomycin. Cells were allowed to adhere for $6 \mathrm{~h}$, then medium was replaced with serum-free DMEM and cells were starved for $24 \mathrm{~h}$. Cells were treated with $350 \mathrm{ng} / \mathrm{ml}$ purified IGFBP-6 protein in the presence or absence of $50 \mathrm{ng} / \mathrm{ml}$ recombinant human IGF-II (Sigma, Vienna, Austria) in serum-free DMEM for $20 \mathrm{~min}$ at $37^{\circ} \mathrm{C}$. As a control, a corresponding volume of buffer solution $(50 \mathrm{mM}$ sodium phosphate, $100 \mathrm{mM} \mathrm{NaCl}, \mathrm{pH}$ 7.0) was used. All corresponding mixtures were pre-incubated for $30 \mathrm{~min}$ at $37^{\circ} \mathrm{C}$ before the experiment was initiated. After $20 \mathrm{~min}$ incubation, cells were washed twice with ice-cold PBS and harvested in a buffer containing $50 \mathrm{mM}$ sodium phosphate, $150 \mathrm{mM} \mathrm{NaCl}, 1 \%$ Nonidet P40, $0.1 \%$ SDS, $0.5 \%$ sodium deoxycholate, $2 \mathrm{mM}$ EDTA, $10 \mathrm{mM} \mathrm{NaVO}, 5 \mathrm{mM} \mathrm{NaF}$, and $10 \mathrm{mM} \beta$-glycerophosphate (pH 7.8). The lysates were incubated for $30 \mathrm{~min}$ on ice, centrifuged at $20,000 \mathrm{~g}$ for $15 \mathrm{~min}$ at $4^{\circ} \mathrm{C}$, and equal protein quantities were separated by SDS-PAGE and transferred to PVDF membranes. Protein concentrations were determined by Bradford assay (Wagner et al. 2001). Levels of phospho-Akt and Akt1 were assessed by Western blot using rabbit polyclonal phospho-Akt (Ser473) antibody (Cell Signaling Technology, Frankfurt am Main, Germany) and goat polyclonal AKT1 (D-17) antibody (Santa Cruz Biotechnology, Heidelberg, Germany). Actin levels were assessed as a loading control by rabbit monoclonal actin antibody (Epitomics, Burlingame, CA, USA).

\section{Labeling of purified IGFBPs with AlexaFluor 647}

$100 \mu \mathrm{g}$ of purified IGFBP-6 or IGFBP-3 (Pircher et al. 2010) protein (in $50 \mathrm{mM}$ sodium phosphate, $100 \mathrm{mM} \mathrm{NaCl}, \mathrm{pH}$ 7.0) at a concentration of $1 \mathrm{mg} / \mathrm{ml}$ were fluorescence-labeled using AlexaFluor 647 Monoclonal Antibody Labeling Kit (Molecular Probes Invitrogen, Lofer, Austria) according to the manufacturer's protocol. Briefly, IGFBP-6 or IGFBP-3 protein was incubated with AlexaFluor 647 dye for $1 \mathrm{~h}$ at room temperature. Unbound dye was removed by applying the complex to the resin column.

\section{Endocytosis assay}

For confocal live cell imaging analysis of IGFBP-6 and IGFBP-3 uptake, U-2OS cells were plated at a density of 50,000 cells per well in the 8-well Lab-Tek Chamber Slide System (Nalge Nunc International, Naperville, IL, USA) and transiently transfected with $0.3 \mu \mathrm{g}$ of pNup153-EGFP plasmid (kindly provided by Dr. Jan Ellenberg, Heidelberg, Germany) and $1 \mu \mathrm{l}$ Lipofectamine 2000 (Invitrogen). On the next day the medium was replaced, and experiments were initiated by the addition of AlexaFluor 647-labeled IGFBP- 6 or -3 at the final concentration of $10 \mu \mathrm{g} / \mathrm{ml}$ in serum-free DMEM supplemented with $4 \mathrm{mM}$ L-glutamine, $100 \mathrm{U} / \mathrm{ml}$ penicillin with $0.1 \mathrm{mg} / \mathrm{ml}$ streptomycin, and 25 mM HEPES (Gibco Invitrogen, Lofer, Austria). Cells were monitored $2 \mathrm{~h}$ after the addition of IGFBP- 6 or -3 using the microlens-enhanced Nipkow disk-based confocal system UltraVIEW RS (Perkin Elmer, Wellesley, MA, USA) mounted on an Olympus IX-70 inverse microscope (Olympus, Nagano, Japan). Images were acquired using a $100 \times$ oil immersion objective (Olympus, PlanApo, 1.4 NA). Image acquisition and analysis were performed using the UltraVIEW RS software (Perkin Elmer, Wellesley, MA, USA).

\section{IGF-II cell binding assay}

100,000 U-2OS cells were seeded on cover slips (15 mm diameter) in 12-well plates in DMEM supplemented with $10 \%$ FCS. On the next day the medium was replaced by serum-free DMEM and cells were starved for $24 \mathrm{~h}$. Cells were then incubated with $50 \mathrm{ng} / \mathrm{ml}$ of biotinylated human IGF-II (IBT Systems, Reutlingen, Germany) in the presence or absence of $500 \mathrm{ng} / \mathrm{ml}$ purified IGFBP-6 protein for $2 \mathrm{~h}$ at $4^{\circ} \mathrm{C}$. Cells were washed $3 \times$ with PBS, fixed with ice-cold methanol/acetone (1:1) fixative for $2 \mathrm{~min}$ at $-20^{\circ} \mathrm{C}$, and dried for $30 \mathrm{~min}$ at RT. Cover slips were rehydrated with PBS and incubated in blocking buffer (1\% BSA in PBS) for $20 \mathrm{~min}$ at RT. Afterwards, cover slips were treated with $1.5 \mu \mathrm{g} / \mathrm{ml}$ Streptavidin-AlexaFluor 488 conjugate (Invitrogen, Lofer, Austria) and $1 \mu \mathrm{g} / \mathrm{ml}$ of nuclear marker TOPRO-3 (Invitrogen, Lofer, Austria) in blocking buffer. After $1 \mathrm{~h}$ of incubation, slides were washed with PBS and embedded in $10 \mu \mathrm{l}$ of DABCO mounting medium. Analysis was performed by confocal microscopy (Zeiss Axiophot) at $40 \times$ magnification.

\section{Results}

Production of native IGFBP-6 in human osteosarcoma cells

For the production of native IGFBP-6 in its physiologically available form, U-2OS osteosarcoma cells were stably transfected with an expression vector, where the fulllength IGFBP-6 cDNA, including the leader peptide sequence, was expressed from a CMV promoter construct. The production of IGFBP- 6 by 24 isolated single clones was monitored by ELISA, and the clone with the highest production rate was selected for further analysis. To avoid possible complications during purification due to the presence of serum, as observed with IGFBP-3 (Pircher et al. 2010), IGFBP-6 expressing cells were washed and subsequently grown in serum-free medium for 3 days. The conditioned medium was harvested and 7 times replaced by 
serum-free medium. Analysis of supernatants by silver staining demonstrated that contamination with serum albumin (approx. $70 \mathrm{kDa}$ ) was negligible (Fig. 1a). To monitor production of IGFBP-6 under these conditions, supernatants were separated by gel electrophoresis and analyzed by Western blot using IGFBP-6 antibodies. Irrespective of serum growth factors, the cells maintained production of IGFBP- 6 in all conditioned media, peaking during harvests 3-6 (Fig. 1b). Several O-glycosylation sites were reported for IGFBP-6 (Neumann et al. 1998). Accordingly, IGFBP-6 from U-2OS supernatants was found to comprise several protein species in the molecular weight (MW) range between 30 and $36 \mathrm{kDa}$ (Fig. 1b).

Pre-purification by cation exchange and hydrophobic interaction chromatography

Like IGFBP-3 and -5, IGFBP-6 contains a heparin-binding consensus sequence in its $\mathrm{C}$-terminal domain, albeit with an approximately 10 -fold lower binding affinity (Fowlkes et al. 1997). Whereas we reported the purification of IGFBP-3 directly from cellular supernatants by heparin affinity chromatography (Pircher et al. 2010), IGFBP-6 from conditioned media did not bind to the heparin agarose column when assayed directly (A. Taferner et al., unpublished). Accordingly, a pre-purification procedure had to be designed, taking into account the known physicochemical properties of the protein. While the theoretical $\mathrm{pI}$ of IGFBP-6 (lacking its leader sequence) amounts to 7.9, mature IGFBP-6 species were found to exhibit a pI between 4.8 and 5.8 due to various posttranslational modifications (Weber et al. 1999). We found that binding of IGFBP-6 to a cation exchange resin was negligible at neutral $\mathrm{pH}$, whereas efficient binding was achieved at $\mathrm{pH}$ 4.5. Cellular supernatants were $\mathrm{pH}$ adjusted by the addition of concentrated buffer, loaded on a Mono S cation exchange column, and eluted by a salt gradient. Starting at a salt concentration of $250 \mathrm{mM} \mathrm{NaCl}$, a prominent peak was eluted (Fig. S1A). When the fractions of the cation exchange chromatography were analyzed by SDS-PAGE and silver staining (Fig. 2a), we found the majority of IGFBP-6 protein in fractions 1120. The identity of the $34 \mathrm{kDa}$ protein band as IGFBP-6 was confirmed by Western blot (Fig. 2b).

We determined through ammonium sulfate fractionation that IGFBP-6 begins to precipitate above 30\% ammonium sulfate saturation (data not shown). Thus, the concentrated pool of the cation exchange purification was adjusted to this saturation level by addition of ammonium sulfate buffer, and the cleared supernatant was applied to a hydrophobic interaction chromatography (HIC) column. Bound protein was eluted by a decreasing salt gradient, with the main peak emerging at the very end of the gradient
Fig. 1 IGFBP-6 production and harvest. a IGFBP-6 expressing $\mathrm{U}-2 \mathrm{OS}$ cells were expanded in DMEM containing $10 \%$ fetal bovine serum and subsequently grown in serum-free DMEM. Every 3 days the supernatant was replaced by fresh serumfree medium and again conditioned for 3 more days. The experiment was terminated after 8 cycles of media conditioning, and eight subsequent supernatants (\#1 through 8) were collected and analyzed by SDSPAGE as indicated. Subsequently, the gel was silver stained. M: molecular weight markers. b Supernatants shown in panel a were analyzed by Western blotting, using antibodies to IGFBP-6. Supernatants contain several IGFBP-6 forms of slightly different MW (see below, Fig. 4) which migrated as a broad band in this experiment

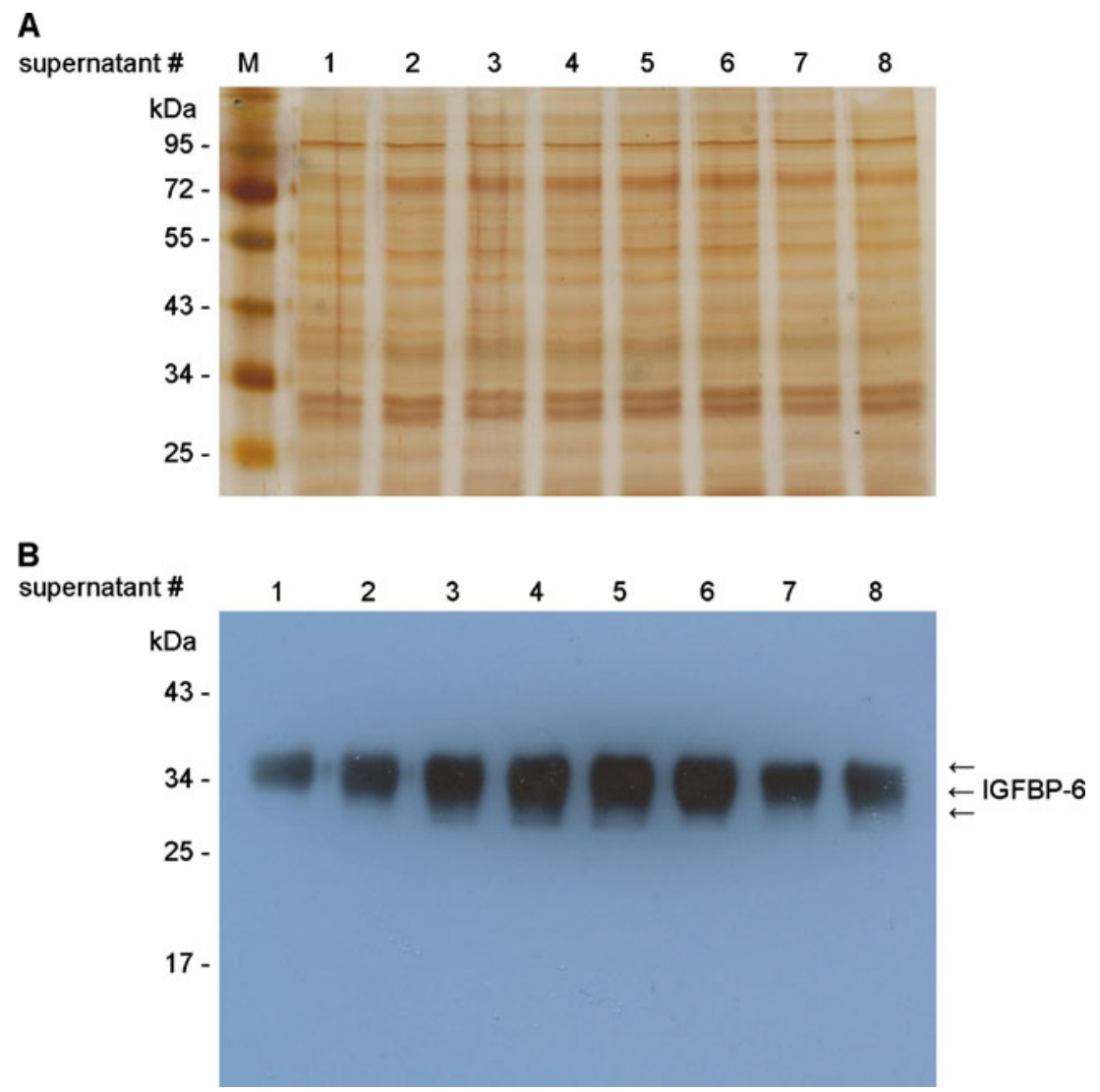



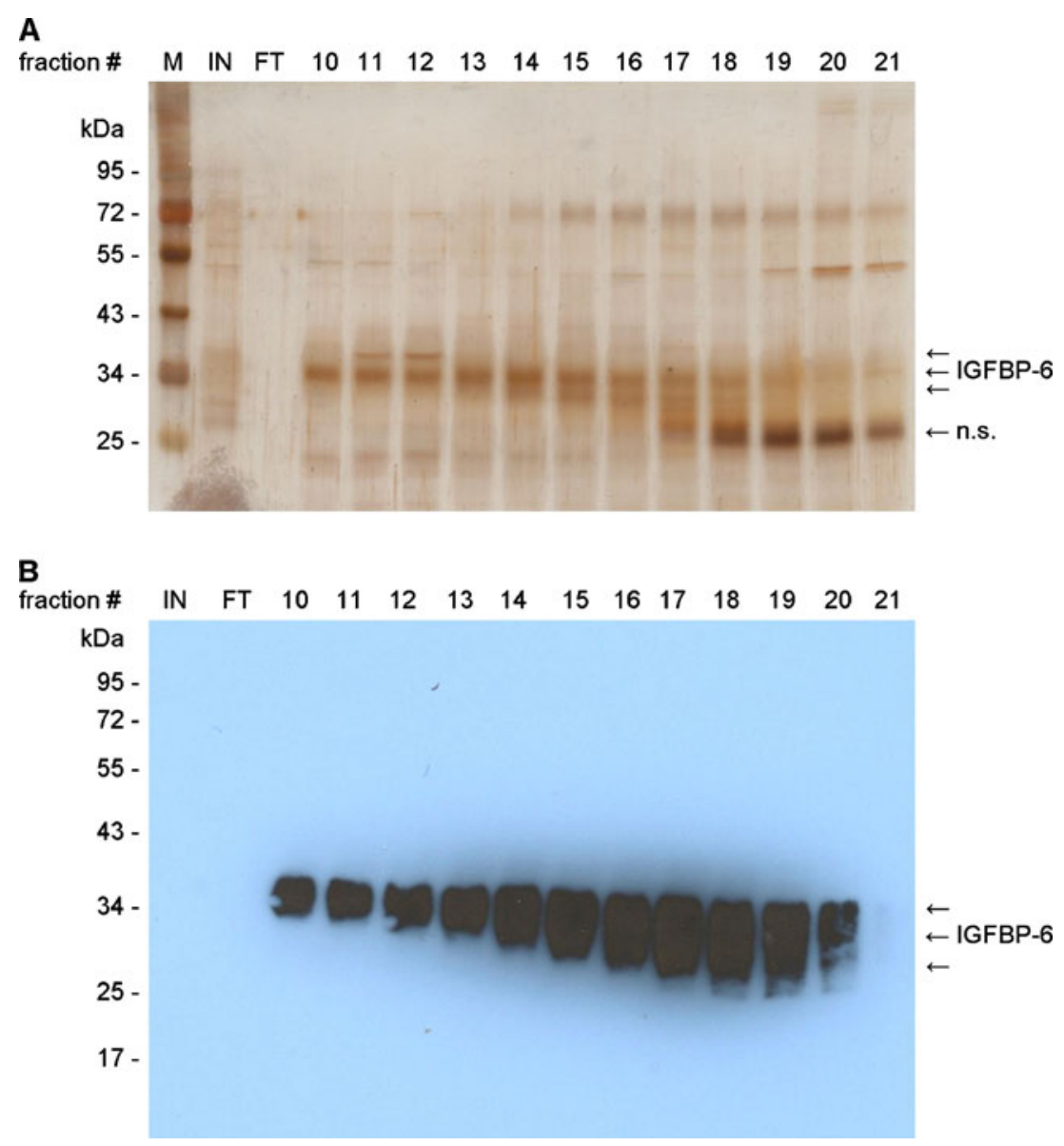

Fig. 2 IGFBP-6 purification by cation exchange chromatography. a Selected fractions obtained by Mono $\mathrm{S}$ chromatography were separated by SDS-PAGE along with molecular weight markers $(M)$, column input $(I N)$, and column flow-through $(F T)$, as indicated. The gel was silver stained. The positions of IGFBP-6 protein species as deduced from comparison with Western blot analysis (see below, panel b) are indicated. n.s. marks a non-specific band representing a protein of approx. $25 \mathrm{kDa}$ that is not recognized by IGFBP-6 antibodies. b Fractions derived from Mono $\mathrm{S}$ purification were separated by SDS-PAGE as shown in panel a, transferred to a PVDF membrane, and probed with antibodies to IGFBP-6 using Western blot. Designation of lanes is as in panel a. Please note that for this and the following Western blots, the IGFBP-6 antibodies were diluted $1: 40,000$, to allow clean identification of IGFBP-6 in highly enriched fractions (e.g. fraction 17). For this reason, the column input is not visible here. The input signal is well visible at higher antibody concentrations, e.g. after dilution 1:2,000 (see Fig. 1b)
(Fig. S1B). Fractions were analyzed by SDS-PAGE and silver staining (Fig. 3a), and we found the majority of IGFBP-6 in fractions 11-19. The identity of IGFBP-6 was confirmed by Western blot (Fig. 3b).

Final purification by heparin affinity chromatography and gel filtration

Fractions 13-21 obtained from the HIC column were salt adjusted and loaded onto a heparin agarose affinity column. The column was eluted with a salt gradient ranging from $50 \mathrm{mM}$ to $1 \mathrm{M} \mathrm{NaCl}$ (Fig. S1C). The protein content of the individual fractions was monitored by silver staining along with the column input and flow-through (Fig. 4a), and IGFBP-6 was identified by Western blot (Fig. 4b). The apparent absence of IGFBP-6 in the flow-through con- firmed that prior purification of IGFBP-6 allows quantitative binding of the protein to the heparin column. At this step of the purification procedure, different MW forms of IGFBP-6 could be detected, probably reflecting differential glycosylation, as was shown for IGFBP-3 before.

After three purification steps as described above, we found IGFBP-6 strongly enriched from the original supernatant. However, an unidentified band with an apparent MW of $25 \mathrm{kDa}$ that was not recognized by IGFBP-6 antibodies still remained as a notable impurity (Fig. 4b). To remove this major contaminant, fractions 4-7 of the heparin purification pool were concentrated and subjected to size exclusion chromatography on a gel filtration column (Fig. S1D). Input, flow-through, and individual fractions were analyzed by SDS-PAGE, silver staining (Fig. 5a), and Western blot (Fig. 5b). Fractions $14-17$ of the gel filtration 
Fig. 3 IGFBP-6 purification by hydrophobic interaction chromatography. a Selected fractions from the hydrophobic interaction column were separated by SDS-PAGE along with molecular weight markers $(M)$, column input $(I N)$, and column flowthrough $(F T)$, as indicated. The gel was silver stained. The positions of IGFBP-6 protein species as defined by Western blot (see below, panel b) are indicated. n.s. depicts a nonspecific protein of approx. $25 \mathrm{kDa}$ that is not recognized by IGFBP-6 antibodies. b Fractions of the hydrophobic interaction column were separated by SDSPAGE as shown in panel a, transferred to a PVDF membrane, and probed with antibodies to IGFBP-6 using Western blot. Designation of lanes is as in panel a
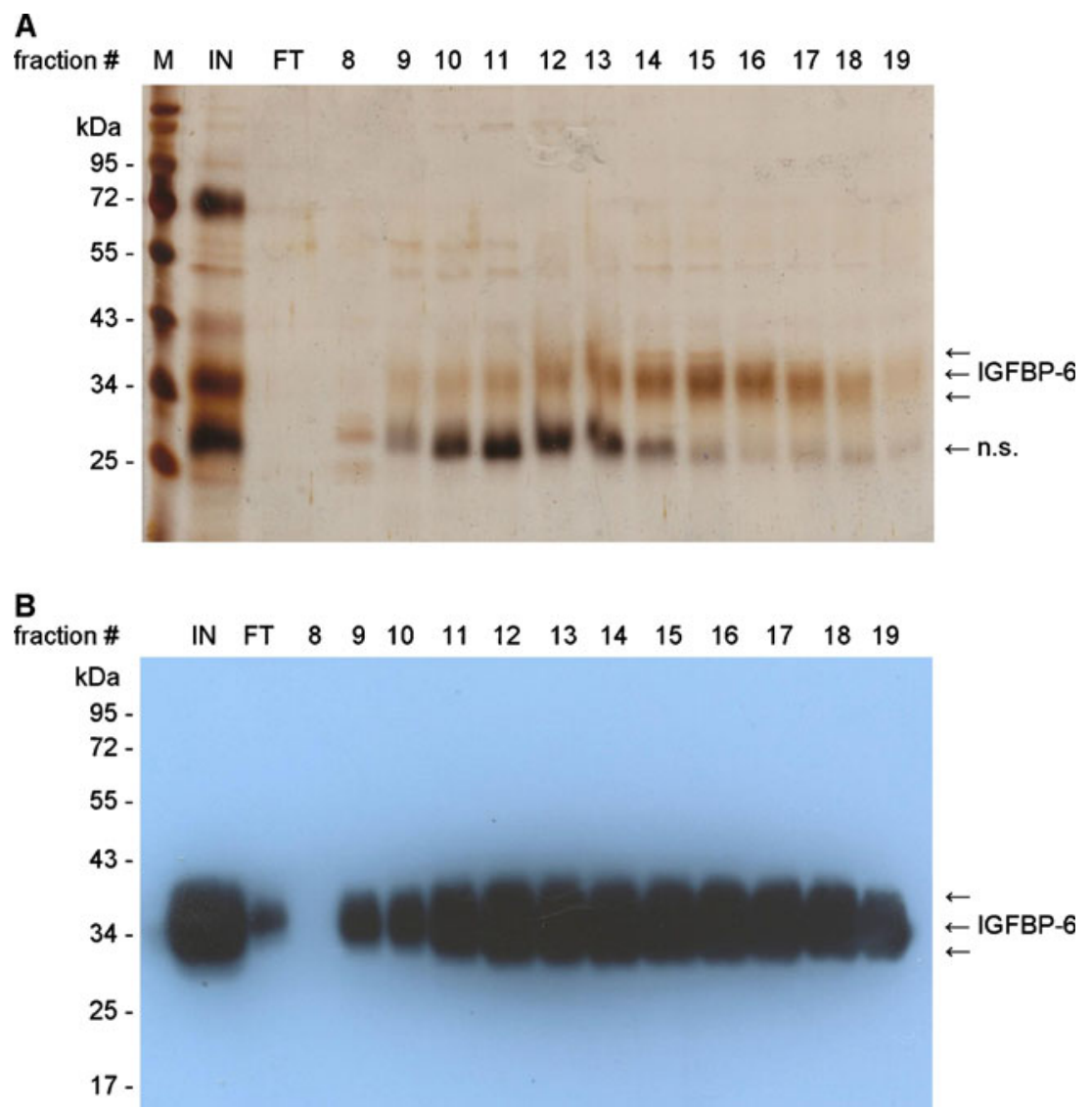

were found to not contain the non-specific band and subsequently pooled.

To assess the degree of purification and the yield of the chromatography procedure shown here, the progressive steps of the IGFBP-6 purification were analyzed on a silver stained gel (Fig. 6) and subjected to ELISA quantification, respectively. This experiment reveals a strong enrichment of IGFBP-6, along with a considerable purification, since all visible impurities have been eliminated by the purification procedure. We found that $230 \mathrm{ml}$ of conditioned medium contained roughly $2 \mathrm{mg}$ of IGFBP-6 (Table 1), and the protein concentration was augmented from $7.9 \mu \mathrm{g} / \mathrm{ml}$ (in the original input) to approx. $1 \mathrm{mg} / \mathrm{ml}$ (in the concentrate of the final fractions). The final concentrated pool derived from the G75 size exclusion chromatography still contained about $1 \mathrm{mg}$ of IGFBP-6, indicating a yield of roughly $50 \%$ (Table 1 ).

Inhibition of IGF signal transduction by purified IGFBP-6

To test the intactness of IGFBP-6 obtained by the purification procedure described here, we performed an IGF Western-ligand blot, demonstrating the ability to bind human IGF-II (Fig. 7a). We also tested the ability of IGFBP-6 to sequester IGF-II and thereby block signaling through the IGF receptor signal transduction pathway.
Human diploid fibroblasts were serum starved for $24 \mathrm{~h}$. Cells were then left untreated or treated with IGF-II for $20 \mathrm{~min}$. IGF receptor dependent signal transduction was monitored by analyzing the phosphorylation of Akt, a major readout of IGF-II signalling (Foulstone et al. 2005). Addition of IGF-II led to a significant increase in Akt phosphorylation with no significant change in the abundance of the Akt protein (Fig. 7b). Addition of IGFBP-6 at a concentration of $350 \mathrm{ng} / \mathrm{ml}$ led to a complete and specific downregulation of Akt phosphorylation (Fig. 7b), suggesting that IGFBP-6 after recombinant expression in mammalian cells and purification by four-step chromatography retained biological activity.

As further proof of functionality, we tested the ability of purified IGFBP-6 to block binding of IGF-II to the cell surface. Serum-starved U-2OS cells were treated with biotinylated IGF-II in presence or absence of purified IGFBP-6. Incubation was done at $4{ }^{\circ} \mathrm{C}$ to inhibit endocytosis. Staining with a Streptavidin fluorescence marker demonstrated that accumluation of IGF-II at the cell surface is strongly reduced in presence of IGFBP-6 (Fig. 8).

IGFBP-6 is not internalized by human osteosarcoma cells

To assess potential cellular uptake of IGFBP-6 by endocytosis, IGFBP-6 was labeled by AlexaFluor 647 and added 
Fig. 4 IGFBP-6 purification by heparin affinity chromatography. a Selected fractions from the heparin agarose column were separated by SDS-PAGE along with molecular weight markers $(M)$, column input $(I N)$, and column flow-through (FT), as indicated. The gel was silver stained. b Fractions of the heparin column were separated by SDS-PAGE as shown in panel a, transferred to a PVDF membrane, and probed with antibodies to IGFBP-6 using Western blot. Designation of lanes is as in panel a. Please note that elution from the heparin affinity column reveals several distinct forms of IGFBP-6, probably differing in the extent of glycosylation, similar to previous findings with IGFBP-3 (Pircher et al. 2010)
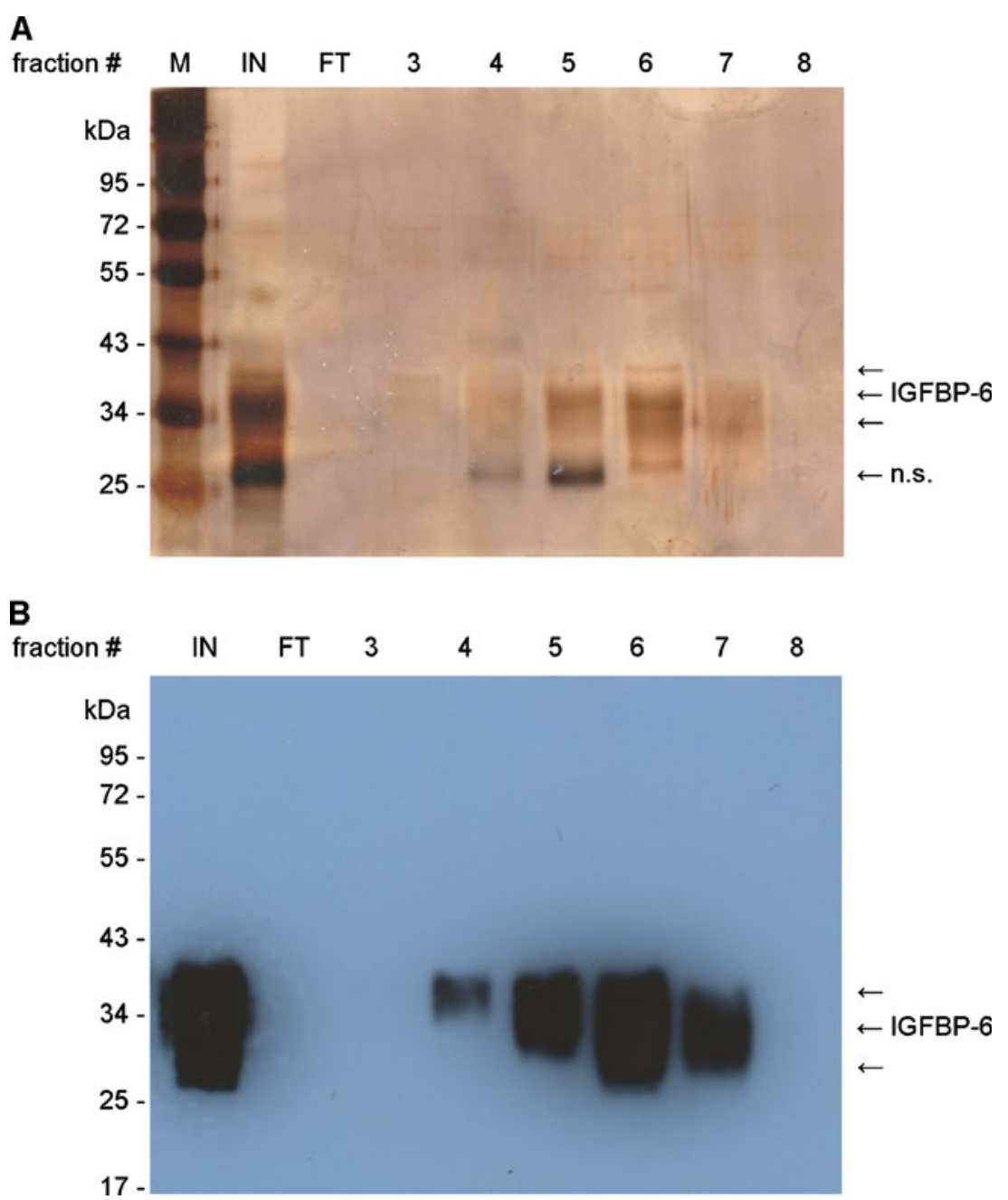

to U-2OS cells transiently expressing a nucleoporin183GFP fusion protein (pNup153-EGFP) used here to visualize the nuclear envelope (Rabut et al. 2004). Purified IGFBP-3 (Pircher et al. 2010) was labeled in the same way und used as a control. While fluorescent labeled IGFBP-3 was readily internalized after $2 \mathrm{~h}$, accumulating in vesicular structures, no uptake was observed for IGFBP-6 within this time frame (Fig. 9).

\section{Discussion}

We describe here a new procedure for the recombinant production and subsequent purification to apparent homogeneity of IGF-binding protein-6. This was achieved by four subsequent chromatographic steps, which resulted in highly pure protein with acceptable yield (approx. 50\%). We also established that IGFBP-6 prepared by this procedure retained its biological activity. Moreover, we provide data that cellular uptake of IGFBP-6 is restricted with respect to other proteins such as IGFBP-3.
A new protocol for purification of native human IGFBP-6

In this communication, we have established a new protocol for the production and purification of recombinant human IGFBP-6 in a human cell type. Higher expression levels and yields of IGFBP-6 would be achievable in bacteria or primitive eukaryotes, thereby simplifying purification. For example, purification of recombinant hIGFBP-6 from Pichia pastoris has been reported to yield approx. $60 \mathrm{mg} /$ liter culture medium (Chen et al. 2007). However, expression in human cells ensures authentic posttranslational modification and processing of hIGFBP-6, which may prove important for biological studies and potential therapeutic use. Small differences in apparent molecular weight were reported when comparing hIGFBP6 purifications from different sources (Chen et al. 2007; Martin et al. 1990), which suggest differences in posttranslational modifications, of unknown significance. For these reasons, we prefer the production of recombinant protein in conditioned media of human cell lines. By utilizing a U-2OS based expression system driven by a 
Fig. 5 IGFBP-6 purification by size exclusion chromatography. a Selected fractions from the gel filtration column were separated by SDS-PAGE along with molecular weight markers $(M)$ and column input $(I N)$, as indicated. The gel was silver stained. b Fractions of the gel filtration column were separated by SDS-PAGE as shown in panel a, transferred to a PVDF membrane, and probed with antibodies to IGFBP-6 using Western blot. Designation of lanes is as in panel a
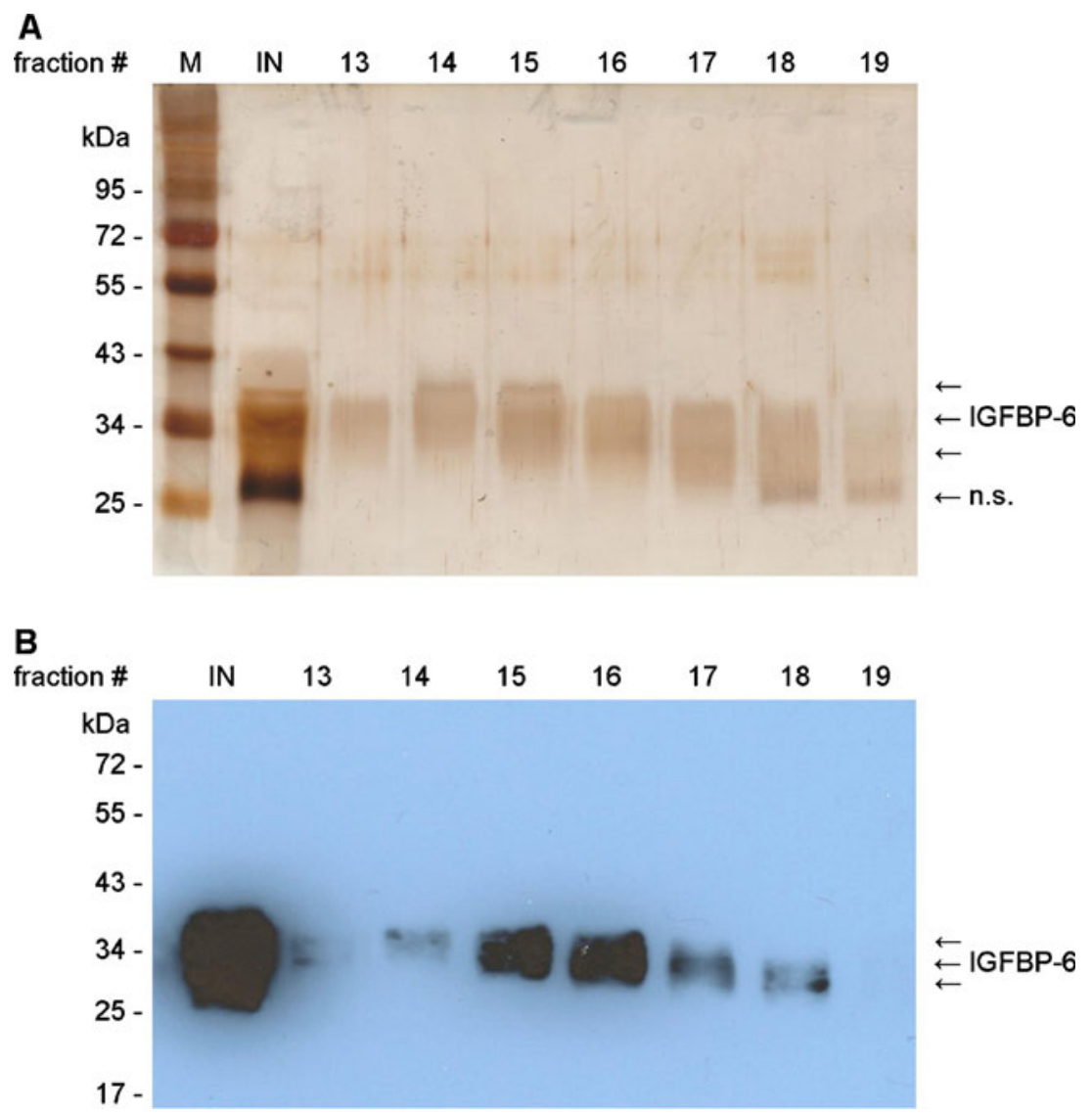

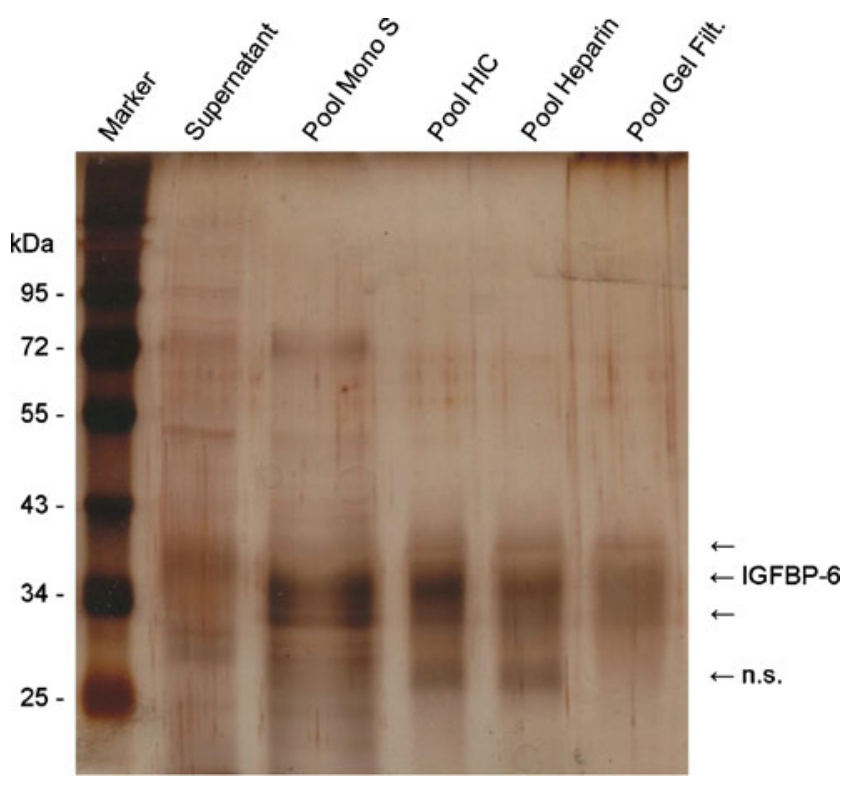

Fig. 6 Analysis of IGFBP-6 purity. Aliquots of the cellular supernatant, the pooled Mono S fractions, the pooled HIC fractions, the pooled heparin fractions, and the pooled gel filtration fractions were analyzed by SDS-PAGE, as indicated, followed by silver staining. Most visible contaminants, in particular the prominent contaminating protein of approx. $25 \mathrm{kDa}$ (nonspecific: n.s.), have been removed during the purification
CMV promoter construct, we achieved IGFBP-6 concentrations of up to $10 \mathrm{mg} /$ liter of cellular supernatant. We avoided possible complications due to the presence of serum proteins, as observed for the purification of IGFBP-3 (Pircher et al. 2010), by growing the cells in serum-free medium.

While purification of IGFBP-6 by IGF-II affinity chromatography, followed by reverse-phase HPLC, has been reported (Srinivasan et al. 1996), we opted against this strategy, thus allowing the future use of our protocol for the purification of IGFBP-6 mutants lacking IGF-II binding activity. IGFBP-6 has been successfully purified as a $\mathrm{His}_{6}$ tagged protein (Headey et al. 2004), but we wanted to avoid the possible drawbacks related to the use of a tagged protein, and concentrated instead on the physicochemical properties as well as the heparin binding affinity of IGFBP6. Strong enrichment of IGFBP-6 from the cellular supernatant proved to be necessary before quantitative binding to a heparin column could be achieved, apparently due to the 10-fold lower heparin affinity in comparison to other IGFBPs (Fowlkes et al. 1997). We achieved this enrichment by a pre-purification protocol, combining ion exchange and hydrophobic interaction chromatography, leading to the removal of the majority of contaminants. After successful heparin affinity chromatography, one significant contaminant, representing an unknown protein species of ca. $25 \mathrm{kDa}$ apparent molecular weight, remained. 
Table 1 Overview of IGFBP-6 purification

\begin{tabular}{lccr}
\hline Sample & Volume & IGFBP-6 conc. & IGFBP-6 total \\
\hline Mono S Input & $255 \mathrm{ml}$ & $7.93 \mu \mathrm{g} / \mathrm{ml}$ & $2,022 \mu \mathrm{g}$ \\
Mono S Pool & $8.60 \mathrm{ml}$ & $0.186 \mathrm{mg} / \mathrm{ml}$ & $1,600 \mu \mathrm{g}$ \\
HIC Pool & $1.49 \mathrm{ml}$ & $0.788 \mathrm{mg} / \mathrm{ml}$ & $1,174 \mu \mathrm{g}$ \\
Heparin Pool & $0.75 \mathrm{ml}$ & $1.388 \mathrm{mg} / \mathrm{ml}$ & $1,041 \mu \mathrm{\mu g}$ \\
Gel Filtration Pool & $0.97 \mathrm{ml}$ & $1.024 \mathrm{mg} / \mathrm{ml}$ & $993 \mu \mathrm{gg}$ \\
\hline
\end{tabular}

For each of the chromatographic steps, the volume of the pooled IGFBP-6 containing fractions is indicated. IGFBP-6 concentration in each pool was determined by ELISA, and the total yield of IGFBP-6 was calculated for each step

This band might represent a proteolytic fragment of IGFBP-6, as was reported to occur during the purification of hIGFBP-6 from Pichia pastoris (Chen et al. 2007), however, the band was not recognized by IGFBP-6 antibodies in Western blot. Whereas this observation may reflect the absence of the epitope recognized by the antibodies, this was not further investigated. Successful removal of this contaminant was achieved by size exclusion chromatography as a final purification step.

Functional characterization of native human IGFBP-6

IGF binding proteins play an important role in modulating the proliferative effects of IGFs and are the subject of increasing investigation (Hwa et al. 1999). Moreover, there is now solid evidence suggesting that some of the IGFBPs, including IGFBP-6, have biological activity that is inde-

\section{A}

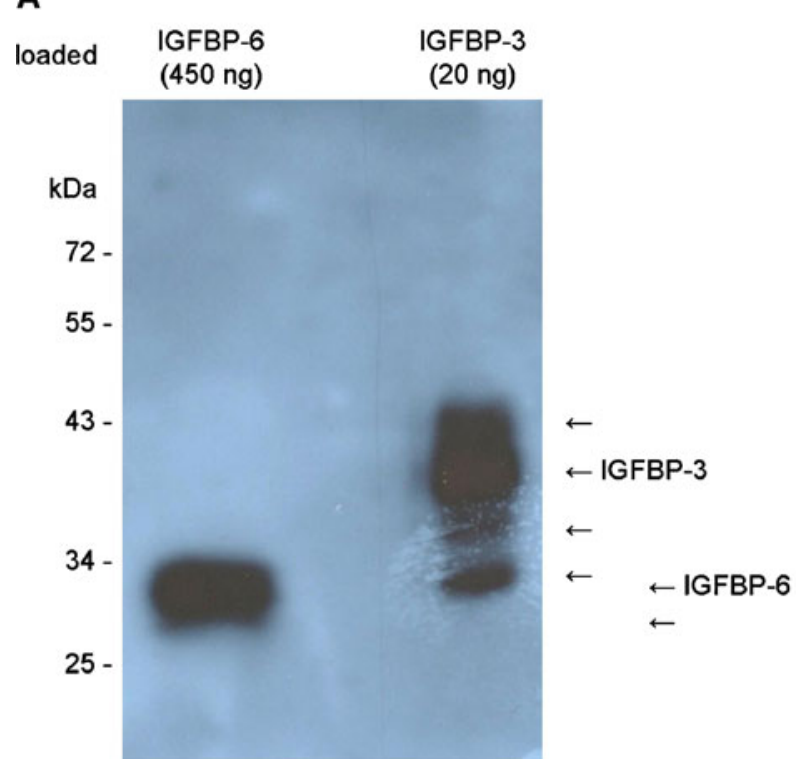

Fig. 7 Functional analysis of purified IGFBP-6. a $450 \mathrm{ng}$ of purified IGFBP- 6 and $20 \mathrm{ng}$ of purified IGFBP-3 were separated by SDS$\mathrm{PAGE}$ as indicated, transferred to a PVDF membrane, and probed with biotinylated human IGF-II using an IGFBP Western-ligand blotting kit. Protein species binding to biotinylated IGF-II are indicated in each case. b Diploid human fibroblasts were serum starved for $24 \mathrm{~h}$ and pendent of their effect on the IGF pathway (Fu et al. 2010). IGF-independent functions were also linked to intracellular IGFBP-6 and its nuclear uptake (Iosef et al. 2010).

The major advantage of the procedure described here is the possibility to produce high amounts of native and biologically active IGFBP-6 from human cell supernatants, which can be used for a variety of biological assays. This is demonstrated in the functional experiments, where we found that $350 \mathrm{ng} / \mathrm{ml}$ of IGFBP-6 completely blocked Akt phosphorylation induced by IGF-II. Although it is known that IGFBP-6 interacts with IGF-II with about 50-fold higher affinity compared to IGF-I, still the interaction of IGFBP-3, known to interact primarily with IGF-I, with IGF-II was much higher compared to IGFBP-6, at least in Western ligand blotting shown here. The limited sensitivity of Western ligand blotting for the identification of IGFBP-6 has been noted in earlier studies (Srinivasan et al. 1996). As

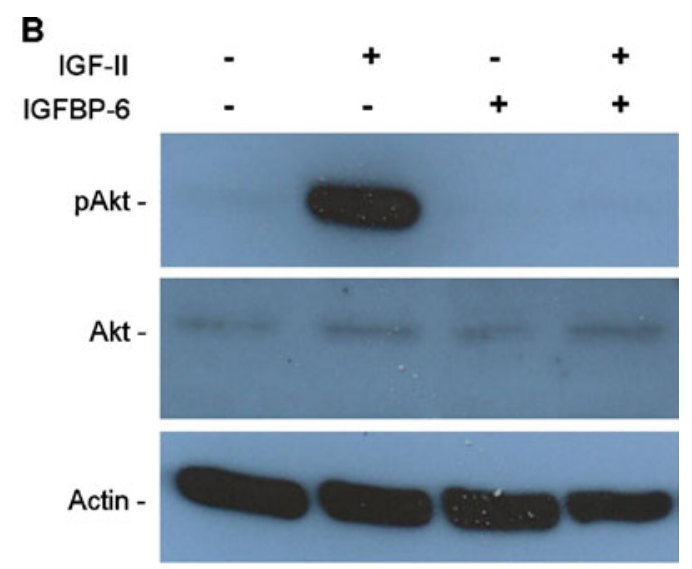

then incubated with $50 \mathrm{ng} / \mathrm{ml}$ of IGF-II or left untreated, as indicated. Where indicated, $350 \mathrm{ng} / \mathrm{ml}$ IGFBP-6 was added. Cellular extracts were prepared and probed with antibodies to Akt, phospho-Akt, and actin, as indicated. The data suggest that IGFBP-6 abrogates IGF receptor dependent signal transduction pathway 
Fig. 8 Study of influence of IGFBP-6 on IGF-II cell binding. Serum-starved U-2OS cells were left untreated or incubated with biotinylated IGF-II in presence or absence of purified IGFBP- 6 at $4{ }^{\circ} \mathrm{C}$. After washing and fixation, cells were treated with Streptavidin-AlexaFluor 488 for detection of IGF-II (green fluorescence) and nuclear marker TO-PRO-3 (red fluorescence) and analyzed by confocal microscopy. Representative images are shown. Bar, $20 \mu \mathrm{m}$

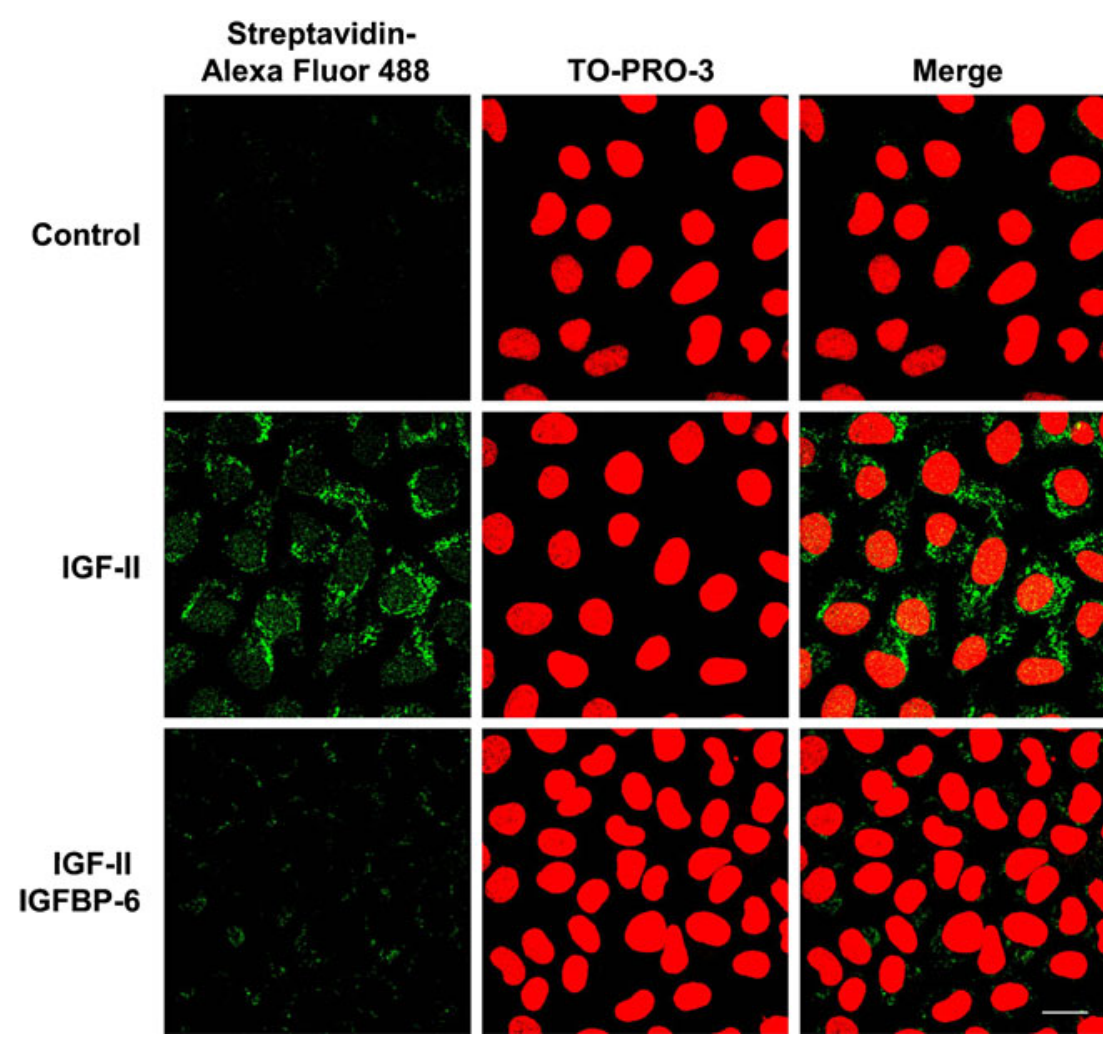

further proof for the inhibition of IGF signal transduction by purified IGFBP-6, we demonstrated that IGFBP-6 blocks the ability of IGF-II to bind to the cell surface of U-2OS osteosarcoma cells. In accordance to existing data, like IGFBP-6 species analyzed from human cerebrospinal fluid (Weber et al. 1999), results reported here suggest that upon purification, in particular during heparin affinity chromatography, different isoforms of IGFBP-6 with slightly different MW, probably reflecting differential glycosylation, can be separated.

We also used the IGFBP-6 produced by our new purification method to study its potential uptake by U-2OS cells. In contrast to IGFBP-3, which is readily internalized by these cells, no short-term uptake of IGFBP-6 was observed by us. Recent studies have shown that cellular uptake of IGFBP-3 and -5 fusion proteins can be inhibited by addition of heparin (Goda et al. 2008), indicating that endocytosis of these proteins is mediated by interaction with cell surfacebound heparin. Taking into account the significantly reduced heparin affinity of IGFBP-6 in comparison to other members of the IGFBP protein family (Fowlkes et al. 1997), this may explain the lack of IGFBP-6 internalization in our experiments. The intracellular, and in particular the nuclear, mode of action of IGF binding proteins has been the subject of ongoing debate in the field, and the current view is that prototypical IGFBP family members, such as IGFBP-3, are internalized by endocytosis before they reach the nucleus (Lee et al. 2004), although the uptake route from endosomes to the nucleus has not been fully elucidated. Our finding
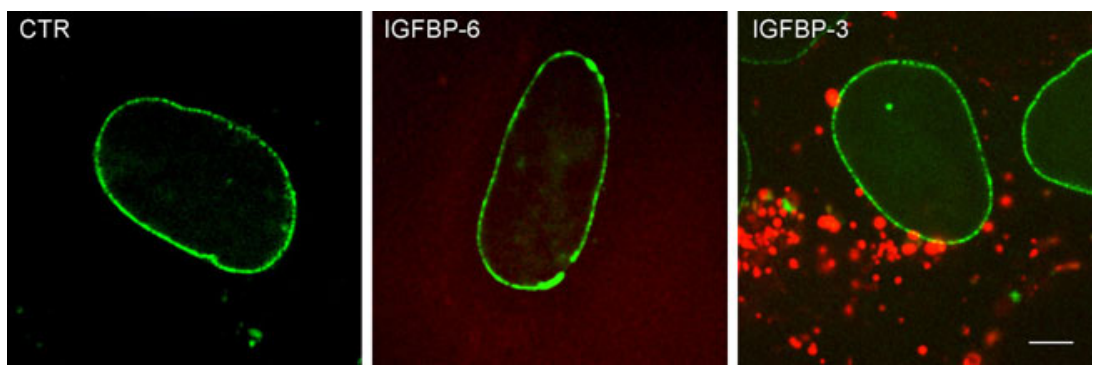

Fig. 9 Study of cellular IGFBP-6 uptake by live cell imaging. U-2OS cells were transiently transfected with an expression vector for nucleoporin 153 fused with GFP (green fluorescence). $24 \mathrm{~h}$ after transfection, cells were analyzed by confocal live cell microscopy in the absence of labeled IGFBPs (CTR) and $2 \mathrm{~h}$ after the addition of AlexaFluor 647-labeled IGFBP-6 or IGFBP-3 (red fluorescence). Representative confocal images are shown. Bar, $5 \mu \mathrm{m}$ 
reported here that IGFBP-6 is a poor substrate for the endocytic apparatus adds another piece to this puzzle. It seems that, at least in the case of IGFBP-6, other models of IGFBPs' nuclear actions not involving secretion and reuptake of IGFBP-6 prior to its nuclear import, e.g. a model implying "intracrine mechanisms" (Butt et al. 2003), will have to be reconsidered.

Of note, IGFBP-6 has been shown to act as an oncosuppressor in certain cancer cells; consequently, the application of recombinant IGFBP-6 has been suggested as a new therapeutic strategy of such malignancies (Kuo et al. 2010). This may stimulate interest to use recombinant IGFBP-6 protein as a potential therapeutic agent, as was previously demonstrated for IGFBP-3 (Liu et al. 2005). Recombinant human IGFBP-6 in high purity and produced from human cells would be required for this purpose. Whereas we describe here a procedure suitable for the purification of rhIGFBP- 6 in laboratory scale, additional experiments for upscaling will be required to achieve this goal.

Acknowledgements This work was supported by grants from the Austrian Science Funds (NFN S93) and the European Union (Integrated Project PROTEOMAGE).

Open Access This article is distributed under the terms of the Creative Commons Attribution Noncommercial License which permits any noncommercial use, distribution, and reproduction in any medium, provided the original author(s) and source are credited.

\section{References}

Baxter RC (2000) Insulin-like growth factor (IGF)-binding proteins: interactions with IGFs and intrinsic bioactivities. Am J Physiol Endocrinol Metab 278:E967-E976

Butt AJ, Dickson KA, McDougall F, Baxter RC (2003) Insulin-like growth factor-binding protein-5 inhibits the growth of human breast cancer cells in vitro and in vivo. J Biol Chem 278:2967629685

Cerro JA, Grewal A, Wood TL, Pintar JE (1993) Tissue-specific expression of the insulin-like growth factor binding protein (IGFBP) mRNAs in mouse and rat development. Regul Pept 48:189-198

Chen Z, Chen H, Wang X, Ma X, Huang B (2007) Expression, purification, and characterization of secreted recombinant human insulin-like growth factor-binding protein-6 in methylotrophic yeast Pichia pastoris. Protein Expr Purif 52:239-248

Dailly YP, Zhou Y, Linkhart TA, Baylink DJ, Strong DD (2001) Structure and characterization of the human insulin-like growth factor binding protein (IGFBP)-6 promoter: identification of a functional retinoid response element. Biochim Biophys Acta 1518:145-151

Firth SM, Baxter RC (2002) Cellular actions of the insulin-like growth factor binding proteins. Endocr Rev 23:824-854

Foulstone E, Prince S, Zaccheo O, Burns JL, Harper J, Jacobs C, Church D, Hassan AB (2005) Insulin-like growth factor ligands, receptors, and binding proteins in cancer. J Pathol 205:145-153
Fowlkes JL, Thrailkill KM, George-Nascimento C, Rosenberg CK, Serra DM (1997) Heparin-binding, highly basic regions within the thyroglobulin type-1 repeat of insulin-like growth factor (IGF)-binding proteins (IGFBPs) $-3,-5$, and -6 inhibit IGFBP-4 degradation. Endocrinology 138:2280-2285

Fu P, Thompson JA, Bach LA (2007) Promotion of cancer cell migration: an insulin-like growth factor (IGF)-independent action of IGF-binding protein-6. J Biol Chem 282:22298-22306

Fu P, Liang GJ, Khot SS, Phan R, Bach LA (2010) Cross-talk between MAP kinase pathways is involved in IGF-independent, IGFBP-6induced Rh30 rhabdomyosarcoma cell migration. J Cell Physiol 224:636-643

Gallicchio MA, Kneen M, Hall C, Scott AM, Bach LA (2001) Overexpression of insulin-like growth factor binding protein-6 inhibits rhabdomyosarcoma growth in vivo. Int J Cancer 94:645651

Goda N, Tenno T, Inomata K, Shirakawa M, Tanaka T, Hiroaki H (2008) Intracellular protein delivery activity of peptides derived from insulin-like growth factor binding proteins 3 and 5. Exp Cell Res 314:2352-2361

Grellier P, De Galle B, Babajko S (1998) Expression of insulin-like growth factor-binding protein 6 complementary DNA alters neuroblastoma cell growth. Cancer Res 58:1670-1676

Headey SJ, Leeding KS, Norton RS, Bach LA (2004) Contributions of the N- and C-terminal domains of IGF binding protein-6 to IGF binding. J Mol Endocrinol 33:377-386

Holbourn KP, Acharya KR, Perbal B (2008) The CCN family of proteins: structure-function relationships. Trends Biochem Sci 33:461-473

Hong J, Zhang G, Dong F, Rechler MM (2002) Insulin-like growth factor (IGF)-binding protein-3 mutants that do not bind IGF-I or IGF-II stimulate apoptosis in human prostate cancer cells. J Biol Chem 277:10489-10497

Hwa V, Oh Y, Rosenfeld RG (1999) The insulin-like growth factorbinding protein (IGFBP) superfamily. Endocr Rev 20:761-787

Iosef C, Gkourasas T, Jia CY, Li SS, Han VK (2008) A functional nuclear localization signal in insulin-like growth factor binding protein-6 mediates its nuclear import. Endocrinology 149:12141226

Iosef C, Vilk G, Gkourasas T, Lee KJ, Chen BP, Fu P, Bach LA, Lajoie G, Gupta MB, Li SS, Han VK (2010) Insulin-like growth factor binding protein-6 (IGFBP-6) interacts with DNA-end binding protein $\mathrm{Ku} 80$ to regulate cell fate. Cell Signal 22:1033-1043

Kim HS, Nagalla SR, Oh Y, Wilson E, Roberts CT Jr, Rosenfeld RG (1997) Identification of a family of low-affinity insulin-like growth factor binding proteins (IGFBPs): characterization of connective tissue growth factor as a member of the IGFBP superfamily. Proc Natl Acad Sci USA 94:12981-12986

Kim EJ, Kang YH, Schaffer BS, Bach LA, MacDonald RG, Park JH (2002) Inhibition of Caco-2 cell proliferation by all-trans retinoic acid: role of insulin-like growth factor binding protein-6. J Cell Physiol 190:92-100

Kuo YS, Tang YB, Lu TY, Wu HC, Lin CT (2010) IGFBP-6 plays a role as an oncosuppressor gene in NPC pathogenesis through regulating EGR-1 expression. J Pathol 222:299-309

Lee KW, Liu B, Ma L, Li H, Bang P, Koeffler HP, Cohen P (2004) Cellular internalization of insulin-like growth factor binding protein-3: distinct endocytic pathways facilitate re-uptake and nuclear localization. J Biol Chem 279:469-476

Liu B, Lee KW, Li H, Ma L, Lin GL, Chandraratna RA, Cohen P (2005) Combination therapy of insulin-like growth factor binding protein-3 and retinoid $\mathrm{X}$ receptor ligands synergize on prostate cancer cell apoptosis in vitro and in vivo. Clin Cancer Res 11:4851-4856

Martin JL, Willetts KE, Baxter RC (1990) Purification and properties of a novel insulin-like growth factor-II binding 
protein from transformed human fibroblasts. J Biol Chem 265:4124-4130

Neumann GM, Marinaro JA, Bach LA (1998) Identification of O-glycosylation sites and partial characterization of carbohydrate structure and disulfide linkages of human insulin-like growth factor binding protein 6 . Biochemistry 37:6572-6585

Perbal B (2004) CCN proteins: multifunctional signalling regulators. Lancet 363:62-64

Pircher H, Matscheski A, Laich A, Hermann M, Moser B, Viertler HP, Micutkova L, Lindner H, Sarg B, Zwerschke W, Jansen-Durr P (2010) A new method for the purification of bioactive insulinlike growth factor-binding protein-3. Protein Expr Purif 71:160 167

Rabut G, Doye V, Ellenberg J (2004) Mapping the dynamic organization of the nuclear pore complex inside single living cells. Nat Cell Biol 6:1114-1121

Schedlich LJ, Le Page SL, Firth SM, Briggs LJ, Jans DA, Baxter RC (2000) Nuclear import of insulin-like growth factor-binding protein- 3 and -5 is mediated by the importin beta subunit. J Biol Chem 275:23462-23470
Srinivasan N, Edwall D, Linkhart TA, Baylink DJ, Mohan S (1996) Insulin-like growth factor-binding protein- 6 produced by human PC-3 prostate cancer cells: isolation, characterization and its biological action. J Endocrinol 149:297-303

Sueoka N, Lee HY, Wiehle S, Cristiano RJ, Fang B, Ji L, Roth JA, Hong WK, Cohen P, Kurie JM (2000) Insulin-like growth factor binding protein- 6 activates programmed cell death in non-small cell lung cancer cells. Oncogene 19:4432-4436

Wagner M, Hampel B, Bernhard D, Hala M, Zwerschke W, JansenDurr P (2001) Replicative senescence of human endothelial cells in vitro involves G1 arrest, polyploidization and senescenceassociated apoptosis. Exp Gerontol 36:1327-1347

Weber MM, Spottl G, Gossl C, Engelhardt D (1999) Characterization of human insulin-like growth factor-binding proteins by twodimensional polyacrylamide gel electrophoresis and Western ligand blot analysis. J Clin Endocrinol Metab 84:1679-1684

Xu XF, Guo CY, Liu J, Yang WJ, Xia YJ, Xu L, Yu YC, Wang XP (2009) Gli1 maintains cell survival by up-regulating IGFBP6 and $\mathrm{Bcl}-2$ through promoter regions in parallel manner in pancreatic cancer cells. J Carcinog 8:13 